\title{
9 The Small Public Limited-Liability Company
}

\subsection{General Remarks}

The purpose of this book is to increase the number of companies with publiclytraded shares and retail investors' direct equity investments. One of the many proposals in this book is to create "the small public limited-liability company" as a new company form for Europe (section 6.4.14).

Like the proposed "microexchange" (section 6.4.13 and Chapter 8), the new company form could be seen as an extreme thought experiment to find out how to make incremental improvements to the current system, or as a radical way to address the problems of the current system. On one hand, the proposed new company form might be politically difficult to achieve. ${ }^{1}$ On the other, it could be regarded as a natural evolution of the model with a small ( $\mathrm{GmbH}, \mathrm{SARL}$ ) and large (AG, SA) limited-liability company. ${ }^{2}$ In any case, the proposed new company form could help to address several complex problems.

First, there is a shortage of small companies with publicly-traded shares. The shortage may partly be caused by company and securities law. The current regulatory framework for companies with publicly-traded shares is designed with large firms in mind. The one-size-fits-all principle of current regulation can make it more difficult for SMEs to go public (sections 1.3 and 5.2). ${ }^{3}$

Second, there is no secondary market for shares subscribed for by early investors in private placements or by crowdfunding contributors in equity crowdfunding. The lack of a secondary market tends to hamper the primary market. Therefore, it could be one of the structural factors that can make high-quality start-ups and growth firms turn to venture capital investors for funding. VC in-

1 See Ghetti R (2018) p 828; Antunes JE, Baums T, Clarke BJ, Conac PH, Enriques L, Hanak AI, Hansen JL, de Kluiver HJ, Knapp V, Lenoir N, Linnainmaa L, Soltysinski S, Wymeersch EO (2011) pp 29 and 31.

2 Giudici P, Agstner P (2019) p 597, Abstract: “[T]he Italian lawmaker has slowly transformed the SRL and created what is basically a new type of company (the SME SRL), which lies in between the two original types but whose borders are not fully clear."

3 See also Hornstein GD (1950) p 1040; Conard AF (1975) p 441: "Fixation on the giants of the corporate world may be quite proper for macroeconomists; the decisions made in the giant corporations supply, in part, the directional signals of United States production and consumption. But the same fixation can be very misleading when applied to the problems of corporate governance. Professor Eisenberg has shown in a recent article that analysis of corporations has been greatly distorted by assuming that all or most corporations are miniature copies of AT\&T and GM.” Citing Eisenberg MA (1969).

Ә OpenAccess. (C) 2022 Petri Mäntysaari, published by De Gruyter. (cc))BY-NC-ND This work is licensed under the Creative Commons Attribution-NonCommercial-NoDerivatives 4.0 International License. https://doi.org/10.1515/9783110761108-010 
vestors tend to prefer a trade sale. At the same time, VC funding tends to exclude the participation of retail investors.

Third, to address those two problems, we propose a new trading venue we call "the microexchange" (Chapter 8). For microexchanges to work, they should earn the trust of retail investors. A microexchange should only be available to companies that fulfil pre-defined minimum requirements. The development of microexchanges must be supported by company law. The provisions of company law and the mechanisms of the microexchange should be developed at the same time to ensure that they are aligned and serve the same goals.

What this means is that the proposed "small public limited-liability company" is not intended as a general-purpose company form for all start-ups. For example, it is not intended as a European alternative to the Delaware corporation. A company law regime based on the use of such a company form would not suffice to create enough companies with publicly-traded shares, because there are problems in the US market as well. More needs to be done. Having said this, the introduction of a functional equivalent to the Delaware corporation or a more flexible company form could help ambitious European start-ups and SMEs in countries that still lack a suitable limited-liability company form for venture capital. ${ }^{4}$ This book focuses on finding alternatives to venture capital and even alternatives to crowdfunding. ${ }^{5}$

Firm size $v$ share ownership, private $v$ public. Even a new company form has its roots in the history of company law. ${ }^{6}$ Both the size of the firm (small v large) and public share ownership (privately held shares v publicly-traded shares) have mattered in company law history. What has been missing is a tailor-made company form for small firms with publicly-traded shares.

The size of the firm has influenced the scope of sector-specific regulation. For example, in EU company law, the statutory audit requirement applies to "public-interest entities, medium-sized and large undertakings" (section 2.4.6). ${ }^{7}$

4 Giudici P, Agstner P (2019) p 598.

5 Compare ibid., pp 614-616 on the Italian search for a company form for tech firms that prefer venture capital and crowdfunding: “Following the 'Restart Italia!' report, the government enacted a 2012 legislative package called 'Growth Decree' (Arts. 25-32 of the Decree Law $18^{\text {th }}$ October 2012, no 179, converted into Law $18^{\text {th }}$ December 2012, no. 221).”

6 In contrast, see Callison W, Fenwick M, McCahery JA, Vermeulen EPM (2018) p 738 on a company form for SMEs: "In particular, in developing a new organizational form of this kind we should not defer to what is already out there or seek to build on some compromise between existing legal approaches."

7 Article 34(1) of Directive 2013/34/EU (Directive on annual financial statements). 
In German corporate governance, mandatory co-determination depends on the company form and the number of employees (section 2.4.10). ${ }^{8}$

The size of the firm has mattered in securities law. Securities law is an important example of sector-specific regulation applicable to companies. While securities law applies to all entities with publicly-traded shares and can in many cases be a functional equivalent to company law (section 4.1), securities law is designed with large firms in mind, making the cost of regulatory compliance in relation to the size of the firm an important issue in securities law discourse.

Company laws have produced different company forms for small firms and large firms (section 2.4.9). For example, the German Aktiengesellschaft (AG) was complemented by the Gesellschaft mit beschränkter Haftung (GmbH) when the German GmbH Act was adopted in 1892. In France, the SARL was created to complement the SA in $1925 .{ }^{9}$ The distinction between the AG and the $\mathrm{GmbH}$, and between the SA and the SARL, became necessary, because a company form designed for large firms, the shares of which often were traded in public, did not suit small firms, the shares of which were held privately.

There are particular provisions of EU company law for legal entities whose shares could be traded in public, that is, "public limited-liability companies" such as the AG and the SA either with or without publicly-traded shares. Public limited-liability companies have been regulated in two ways in EU company law.

First, Member States' company laws were harmonised by many company law directives that focused on public limited-liability companies. Many of the earlier directives have been codified in Directive (EU) 2017/1132. ${ }^{10}$ This Directive also shows why the EU has chosen to focus on public limited-liability companies: "[C]oordination ... is especially important in relation to public limited liability companies because their activities predominate in the economy of the Member States and frequently extend beyond their national boundaries."11 Moreover, "[i]n order to ensure minimum equivalent protection for both shareholders and creditors of public limited liability companies, the coordination of national provisions relating to the formation of such companies and to the maintenance, increase or reduction of their capital is particularly important."12

$8 \S 1$ of Gesetz über die Drittelbeteiligung der Arbeitnehmer im Aufsichtsrat (Drittelbeteiligungsgesetz, DrittelbG). For GmbHs, see §1(1) number 3 of the DrittelbG.

9 Loi du 7 mars 1925 institution des sociétés à responsabilité limitée.

10 Directive (EU) 2017/1132 of the European Parliament and of the Council of 14 June 2017 relating to certain aspects of company law.

11 Recital 2 of Directive (EU) 2017/1132 (Directive relating to certain aspects of company law). 12 Recital 3 of Directive (EU) 2017/1132 (Directive relating to certain aspects of company law). 
Second, there is a particular European company form created by the SE Regulation. ${ }^{13}$ The SE is a public limited-liability company governed by the SE Regulation, the statutes of the SE, and the law of the Member State in which the SE has its registered office. ${ }^{14}$

While the harmonisation of Member States' company laws can be regarded as a success, unified European company forms have not yet become popular. ${ }^{15}$

In any case, there is no tailor-made company form for small firms with publicly-traded shares in the EU. There was a proposal for a company form for small firms with privately held shares. After the adoption of the SE Regulation, the European Commission proposed a Council Regulation on the statute for a European private company (Societas Privata Europaea, SPE). ${ }^{16}$ The SPE proposal of 2008 was perceived as very controversial and the Commission withdrew it in the REFIT Communication of 2013. ${ }^{17}$ The two key reasons for the political failure of the proposal were said to be the lack of adequate provisions on employee participation and the question whether an SPE should be allowed to register in a country other than the country in which its head office is located.

The adopted SE Regulation and the failed proposal for a SPE Regulation can provide useful ideas about how to create a company form for small firms that prefer to have publicly-traded shares. In the EU, the small public limited-liability company would need to be a "small SE", either at national level as a form of regulatory development or competition, or at EU level as a European company form.

Company law history and start-up practice. To create a new public limited-liability company for small firms, we can seek guidance in company law history and start-up practice.

Ways to regulate companies have been tested since the nineteenth century (section 2.4). When regulating companies and corporate governance, it is a good idea to foster the interests of the firm (in German "das Unternehmen”, in French "l'entreprise", section 2.4.13), make the governance model self-enforcing,

13 Council Regulation (EC) No 2157/2001 of 8 October 2001 on the Statute for a European company (SE).

14 Article 9(1) of Regulation 2157/2001 (SE Regulation).

15 See Ghetti R (2018) pp 832-833.

16 Proposal for a Council Regulation on the statute for a European private company, $\operatorname{COM}(2008)$ 396 final.

17 Regulatory Fitness and Performance (REFIT): Results and Next Steps. Communication from the Commission, $\operatorname{COM}(2013) 685$ final. See nevertheless footnote 16: "The Commission is considering presenting a new proposal." 
and make the governance model flexible enough to facilitate innovation (section 2.3.3). ${ }^{18}$

Start-up funding practices have focused on the success of the business venture, that is, the firm. Founders, family, friends, and angel investors have contributed relatively small amounts of capital to the venture in exchange for common stock. ${ }^{19}$

In angel funding practice (sections 5.3 and 6.3.13), angel investors have preferred "informal methods of screening and monitoring entrepreneurs". ${ }^{20}$ They have left plenty of discretion to founders and have not required board seats. ${ }^{21}$

If the business venture grows, the start-up needs to raise new funding. Attractive companies have raised venture capital from investors that subscribe for or buy convertible preferred stock or convertible notes. ${ }^{22}$ An angel investor's financial payoff comes from a small number of start-ups that raise venture capital and provide a successful exit. ${ }^{23}$ These aspects can be taken into account when designing the new company form.

Design principles. To create the small public limited-liability company, regulators should first choose design principles. In this Chapter, we will propose some core design principles. They include the following: use mandatory provisions of law to standardise the company form (section 9.2); make the company form attractive to firms by laying down a board duty to act in the interests of the firm (section 9.3); require a two-tier structure at board level (section 9.4); do not use mandatory co-determination (section 9.5); facilitate electronic voting (section 9.6); facilitate the use of a microexchange (section 9.7); require a low minimum subscribed and paid-for share capital for small public limited-liability

18 See already Mäntysaari P (2012) Chapters 8 and 9.

19 Coyle JF, Green JM (2014) pp 154-155.

20 Ibrahim DM (2008) p 1408.

21 Ibid., pp 1422-1423: “... a fairly consistent picture of angel contract design. They reveal that traditional angels use simpler contracts that are comprised of more entrepreneur-friendly terms than do venture capitalists. As a general rule, these contracts employ none of the five methods venture capitalists have devised to mitigate uncertainty, information asymmetry, and agency costs in start-up investments. First, traditional angels do not stage their investments. [...] Second, the traditional angel receives common instead of preferred stock in exchange for her investment. [...] Third, while board seats are commonly granted in venture capital rounds, they do not appear common in angel rounds. [...] Fourth, few angels contract for negative covenants. Wong's study found that negative covenants allowing investors to veto management decisions were included in only 5.1 percent of angel contracts. [...] Finally, like negative covenants, specific exit rights also may be used less frequently by angels than other venture capital protective devices."

22 Ibid., pp 154-155.

23 Ibrahim DM (2008) p 1408. 
companies in general and a higher share capital for those small public limitedliability companies that want to use a microexchange (section 9.8); permit just one or two classes of shares (section 9.9); ensure pre-emptive rights and the equal treatment of shareholders, but apply pre-emptive rights in a flexible way to facilitate new funding rounds (section 9.10); facilitate exits but ensure protection against the market for corporate control (section 9.11); ensure that the company's capital is used in the interests of the firm (section 9.12); rely on mixed monitoring and public enforcement (section 9.13); and make the change of company form easy (section 9.14).

General company law reform. The proposals could even be used as part of a general company law reform. How such reforms would play out is difficult to predict.

First, all company law reforms are embedded in existing company and commercial law. ${ }^{24}$ The nature of company law as a "matrix" increases the cost of regulatory changes and is one of the causes of path dependency (section 2.3).

Second, company laws are value-based systems (sections 3.4.13 and 6.2). Reforms are more difficult to pull off where the values represented in company law discourse are too heterogeneous. Calls for reforms are currently not based on the same set of values.

Third, company law can be reformed at the national or international level. One can distinguish between unilateral amendment of company law, harmonisation, and unification with unification as the most costly and politically most controversial alternative. ${ }^{25}$

This said, EU company law is facing a new reality after the withdrawal of the UK. There is more room for a European company law reform, because the company laws of the remaining Member States share the same continental European roots and roughly similar values. ${ }^{26}$

24 Ghetti R (2018) p 831: "The regulation of [European company forms] shows that company forms are not independent of national law. The legal unification of company forms would require common rules in lieu of national ones and the complete regulation of all aspects of company life. This is obviously more difficult than mere harmonisation."

25 Ghetti R (2018) pp 817-818 and 836; Giudici P, Agstner P (2019) on the Delaware corporation as a driver of company law change in Italy.

26 Koutsias M (2019). 


\subsection{Mandatory Provisions}

Where the objective is to increase the number of companies with publicly-traded shares and retail investors' direct equity investments by facilitating the operation of a large number of microexchanges, the company law regime should largely consist of mandatory provisions of law that ensure standardisation and increase the transparency of the new company form.

Standardisation is common practice in all organised securities, commodities, and derivatives markets. In organised OTC markets, standardisation is based on standard contracts such as master agreements in addition to the regulation of market participants and market structure. ${ }^{27}$ Regulated equity markets are standardised markets. The public trading of shares does not work without extensive standardisation. The standardised legal framework can be based on company law, securities law, and/or exchange self-regulation. ${ }^{28}$

In the case of the proposed new company form, these rules cannot be made by the exchange or the exchange operator, because there is no traditional exchange. The nominal owner of the proposed microexchange is an SPV belonging to the issuer. Moreover, if the rules were made by the operator of the platform that microexchanges use when organising trading, the platform operator would be regarded as the operator of a regulated market subject to the customary regulatory compliance obligations.

Retail investors are protected by mandatory standards. Companies that issue shares to the public should comply with statutory minimum standards. Properly designed and enforced statutory minimum standards can reduce retail investors' search costs, transaction costs (as the standards are the same for all companies), ${ }^{29}$ and the risk of a market for lemons (as there is no private race to the bottom as far as the standards are concerned). ${ }^{30}$ Standards can be based on compa-

27 See, for example, Regulation 648/2012 (EMIR).

28 This does not apply to micro-, small- and medium-sized enterprises (MSMEs). See Callison W, Fenwick M, McCahery JA, Vermeulen EPM (2018) p739: “[I]n order to be fully successful, any organizational form needs to be flexible enough to accommodate the diversity of MSMEs."

29 Compare Action Plan on Building a Capital Markets Union. Communication from the Commission, $\operatorname{COM}(2015) 468$ final, section 1.3: "The information gap between SMEs and investors can be a hurdle to non-bank funding. In particular, search costs prevent potential investors from identifying and assessing attractive companies in which to invest. There is a need, on the one hand, to make small firms in need of financing better aware of the market-based funding options available to them and, on the other, to make firms more visible to prospective local and pan-European investors."

30 Akerlof GA (1970). Daniel Davies, A scammer's charter for European capital markets. Financial Times, 9 November 2015: “... a push for deregulation always runs the risk of turning into a 
ny law or securities law. Standardisation based on the mandatory provisions of company law could thus help to increase retail investors' direct equity investment. ${ }^{31}$ In fact, this can help to explain the mandatory nature of the provisions of the German Aktiengesetz and the US Securities Acts.

In contrast, a high level of flexibility for a specific company form can increase investors' search and transaction costs and reduce retail investors' direct equity investment. ${ }^{32} \mathrm{~A}$ high level of company law flexibility would therefore need to be complemented by mandatory norms from another source such as securities law or the listing rules of a stock exchange. This is what has happened in the US.

Restricting such flexibility for a new company form would not restrict choice in company law as a whole. The introduction of a new company law regime for small firms with publicly-traded shares would increase choice regardless of whether the new regime consists of mandatory or dispositive provisions of law. The proposed regime would still be complemented by other available company forms. The existence of alternative company forms would ensure a sufficient level of choice and freedom of contract. ${ }^{33}$

The rules of company and securities law should lay down the required structures and standards of behaviour and avoid overreliance on disclosures (sections 3.4.7 and 6.3.12). Clear requirements (the contents of which when applied to future facts can be predicted with reasonable clarity in advance) can increase the transparency of the required standards, help enforcement, increase compliance, and generally influence behaviour. Open standards (the exact contents of which can only be determined after the fact) can fill gaps between the more detailed

'scammer's charter'. Red tape and expense in Europe's equity markets exist for a reason. The barriers that hold back small companies seeking equity financing are also the ones that separate unscrupulous stock promoters from investors' wallets."

31 In contrast, see Kitch EW (2005) pp 36-37 arguing for freedom to choose the regulatory regime: "The argument for issuer and purchaser choice is that purchasers are just as capable of judging the information disclosure and liability regime that they prefer to govern the securities they purchase as they are able to judge the terms of the security, or to make judgments about the economic future of the issuer." This view looks rather optimistic.

32 Compare Kitch EW (2005) p 35: "Corporate law has come to be understood as a system of multi-party contractual relationships, a subpart of contract law. Corporate law provides default rules that can be varied by the parties."

33 Compare Kitch EW (2005) pp 36 - 37: "Roberta Romano has advanced the idea that the contractual choice approach should be extended to securities regulation by amending the securities statutes so that corporate issuers could choose whether to be subject to their requirements ... I argued that the Romano proposal is less radical than it appears because of the influence the contractual idea already has had on securities regulation. For instance, issuers can choose to sell securities under the provisions of the 1933 Securities Act, or they can choose to sell them outside the provisions of the Act by following the procedures for a private placement.” 
requirements. The most important of such standards is the rule that sets out the corporate interest, that is, the interests that corporate bodies are expected to serve when acting as or on behalf of the company (section 2.4.13). ${ }^{34}$

\subsection{Duty to Act in the Interests of the Firm}

The small public limited-liability law should lay down a board duty to act in the interests of the firm (sections 2.4.13, 6.3 .10 and 6.3.11). The same duty should apply to any other statutory body responsible for the administration of the company (such as a managing director or directors).

It is customary to distinguish between the legal entity, the firm (das Unternehmen, l'entreprise), and shareholders in German and French company law. The interests of the company are interpreted as the interests of the firm. The board of a public limited-liability firm thus has a legal duty to act in the interests of the firm (Unternehmensinteresse, l'interêt social). The interests of the firm are long-term.

The notion of the firm customarily is not used in the company law discourse of common law countries. However, the interests of the firm matter in start-up funding practice. Founders turn to angel investors and venture capital investors that can benefit the business venture. Shareholders, employees, law firms, and many other stakeholders are chosen on the basis of how much they can contribute to the success of the firm.

To make company law useful for firms and foster the development of successful firms, the better alternative therefore is to lay down a mandatory duty to act in the interests of the firm. ${ }^{35}$ This means the rejection of both shareholder

34 See also the proposal for a Council Regulation on the statute for a European private company, $\operatorname{COM}(2008) 396$ final, Chapter V: "The Regulation imposes on directors the duty of acting in the best interests of the company ... The Regulation lays down a general standard of care by requiring from directors the care and skill reasonably required in the conduct of business ... Directors are required to avoid any actual or potential conflicts of interests ... The Regulation establishes directors' liability for any loss or damage suffered by the SPE due to the breach of their duties deriving from the Regulation, articles of association or a resolution of shareholders." 35 The SPE proposal used the notion "interests of the company". Proposal for a Council Regulation on the statute for a European private company, $\operatorname{COM(2008)} 396$ final, Explanatory memorandum, Chapter V: "The Regulation imposes on directors the duty of acting in the best interests of the company. Accordingly, directors' duties are owed to the SPE and may only be enforced by the company. The Regulation does not give individual shareholders or creditors the right to directly sue the members of the management body." 
primacy and stakeholder approaches. ${ }^{36}$ The interests of the firm are not the same thing as the interests of its stakeholders, but the firm will need to take any relevant interests into account in order to survive in the long term.

\subsection{A Two-Tier System}

The small public limited-liability should have a two-tier system with either a two-tier board or a board monitoring one or more managing directors. ${ }^{37}$

In late nineteenth-century Germany, it was understood that management and monitoring should be separated at the board level. This led to the German company law reform of 1884 (section 2.4.5). It was also understood that small shareholders make poor monitors due to their limited resources and incentives.

In the EU, the SE Regulation permits choice between "either a supervisory organ and a management organ (two-tier system) or an administrative organ (one-tier system) depending on the form adopted in the statutes" for an SE. ${ }^{38}$ The SPE proposal would have permitted choice between a single director, several directors, a one-tier system, or a two-tier board system in the SPE's articles of association. ${ }^{39}$

To create a self-enforcing governance model with sufficient monitoring without the participation of retail shareholders and institutional investors, a two-tier model with both tiers required to comply with statutory standards looks like a good alternative for the small public limited-liability company. ${ }^{40}$

Under the two-tier model, a board for monitoring (a supervisory board) ${ }^{41}$ monitors a management board responsible for the management of the company

36 See Mäntysaari P (2012) section 6.3.3.

37 See, for example, Hopt KJ (2019b) p 522; Gilson RJ (2014).

38 Article 38 of Regulation 2157/2001 (SE Regulation).

39 Proposal for a Council Regulation on the statute for a European private company, $\operatorname{COM(2008)}$ 396 final, Explanatory memorandum, Chapter V: "All decisions which are not listed in the Regulation or in the articles of association fall under the competence of the SPE's management body which is responsible for running the company. The articles determine the management structure of the SPE (a single director or several directors, a one-tier or a two-tier board system). However, if the SPE is subject to employee participation, the chosen management structure must allow for the exercise of this right. The shareholders of the SPE decide on the appointment and removal of directors."

40 See nevertheless Hopt KJ (2018) arguing for a right to choose between the one-tier and twotier board.

41 See also §§ 111-112 of the German Aktiengesetz (AktG); SEC Release No. 34-86327 (July 8, 2019), I.1(D): "The Exchange believes the boards of directors should be engaged with the 
(such as in a German AG) or one or more managing directors (such as in a German $\mathrm{GmbH}$ ). Members of the management board are the top executives of the company. If the company has one or more managing directors (Geschäftsführer), the managing directors are the top executives of the company.

The independence of the monitoring function can be ensured by structural measures. No person should be member of both bodies at the same time. ${ }^{42}$ Moreover, the two boards should be collegiate organs to ensure peer-to-peer monitoring. ${ }^{43}$ Each member should have a statutory duty to act in the interests of the firm contributing to a more a long-term corporate culture.

Management board members or managing directors should be appointed by the supervisory board. Where management board members, that is, the top executives of the company, are appointed by the supervisory board, they are better shielded against non-controlling shareholders and have more discretion to act in the long-term interests of the firm. ${ }^{44}$

Members of the supervisory board should be appointed by shareholders in general meeting. When company law is based on the design principles of separating functions and avoiding situations of self-interested decision-making (section 2.4.11), shareholders in general meeting end up having this function. One may note that the mere fact that this function is allocated to this or that corporate body says nothing about nominal or beneficial ownership.

Share-based incentives should not be used for the remuneration of supervisory board members in their capacity as supervisory board members.

Generally, the remuneration of each supervisory board or management board member should not exceed what is reasonable. Without any statutory limit, remuneration levels would be likely to rise, because board members and senior managers would have the opportunity and incentives to increase their own pay. ${ }^{45}$ A general open standard of reasonableness should be complemented by a prohibition of the most abusive practices such as golden handshakes.

LTSE-Listed Issuer's forward-looking, long-term strategy, rather than serving primarily an audit function and looking backwards, as many boards seem to today. The Exchange also believes that investors will find this information useful."

42 See also $\S 100$ AktG.

43 Belot F, Ginglinger E, Slovin MB, Sushka ME (2014) p 376 on French companies: "Several proxy variables support the hypothesis that a high potential for private benefit extraction implies that a two-tier board structure is more likely to be an effective solution for corporate governance, consistent with [Adams RB, Ferreira D (2007)]." For private benefit extraction in US companies with a unitary board structure, see Bebchuk LA, Fried JM, Walker DI (2002).

44 Mäntysaari P (2012) Chapter 9.

45 See Bebchuk LA, Fried JM, Walker DI (2002). 
Shareholders should not decide on the remuneration of management board members. Generally, small shareholders are poor monitors. The remuneration of management board members should be decided on by the supervisory board. The allocation of this function to the supervisory board should be complemented by mandatory provisions of company law laying down constraints on remuneration.

The separation of functions leads to shareholders in general meeting deciding on the remuneration of supervisory board members, again subject to constraints laid down by mandatory provisions of company law.

What this also means is that one should not rely on the regulation of shareholders' "say on pay" under the Shareholder Rights Directive (SRD II) ${ }^{46}$ for the proposed new company form. SRD II relies on institutional investors and asset managers as monitors of strategy and long-term performance in listed companies, ${ }^{47}$ and as monitors of the remuneration of each member of the company's administrative, management, or supervisory bodies. According to SRD II, shareholders are able to express their views on remuneration twice. The "say on pay" regime under SRD II would not work for the proposed small public limited-liability company, because this company form is designed for firms with one or more controlling shareholders and many retail investors. Controlling shareholders control the company in any case, and retail investors make poor monitors. Moreover, it is important to simplify the company law regime where possible. This does not exclude adequate disclosures and the right of shareholders to express their opinion. ${ }^{48}$

\subsection{No Mandatory Co-Determination}

The proposed small public limited-liability company should have neither mandatory co-determination nor mandatory employee membership on the supervisory board.

On one hand, the firm could benefit from diversity. Diversity of the work force can increase creativity and innovation. On the supervisory boards of large traditional German firms, employee representatives are used as a comple-

46 Directive (EU) 2017/828 of the European Parliament and of the Council of 17 May 2017 amending directive 2007/36/EC as regards the encouragement of long-term shareholder engagement (SRD II).

47 Recital 15 of Directive (EU) 2017/828 (SRD II).

48 See recital 28 of Directive (EU) 2017/828 (SRD II). 
ment to shareholder representatives to create diversity and improve the quality of monitoring and decision-making. The supervisory board should have access to the know-how of employees. ${ }^{49}$

On the other, one of the reasons that led to the failure of the European Commission's SPE proposal was the Member States' disagreement on whether the SPE should fall within the scope of national employee participation and co-determination laws. The Commission pointed out that the SPE proposal was neutral as far employee participation was concerned. ${ }^{50}$ In Germany, however, mandatory co-determination applies to larger SMEs regardless of the company form. For example, if a GmbH "as a rule" has more than 500 employees, it must have a supervisory board with a third of the seats allocated to employee representatives (section 2.4.10). ${ }^{51}$

The proposed small public limited-liability company should build on the SPE proposal. Since the composition of the supervisory board can influence the firm's survival chances, the general meeting - in practice, the founders or controlling shareholders - should have discretion to appoint supervisory board members.

This does not exclude employee representation on the supervisory board. To create diversity and mixed monitoring, and to improve the quality of monitoring and decision-making, employee representatives generally can be used as a complement to shareholder representatives on the supervisory board. ${ }^{52}$ Many firms do this on a voluntary basis.

In many start-ups, employees in fact are shareholders and knowledgeable about the firm's operations. Employee shareholders can contribute to mixed monitoring as part of the firm's formal or informal governance structure thanks to their actual experience from the firm, first-hand information about its management, and long-term incentives to improve the firm. ${ }^{53}$ In a start-up, the fundamental difference between key employees and various kinds of external investors (such as business angels, an accelerator, or the start-up's law firm) is

49 Compare Hopt KJ (2018) p 277: "So versagt zwar die noch vorherrschende Meinung dem Aufsichtsrat einen direkten Zugriff auf Personal, das dem Vorstand nachgeordnet ist, auch solches in der zweiten Reihe."

50 Proposal for a Council Regulation on the statute for a European private company, $\operatorname{COM}(2008)$ 396 final, Explanatory memorandum, Chapter VI.

$51 \S 1$ of Gesetz über die Drittelbeteiligung der Arbeitnehmer im Aufsichtsrat (Drittelbeteiligungsgesetz, DrittelbG). For GmbHs, see §1(1) number 3 of the DrittelbG.

52 Hopt KJ (2018) p 277.

53 Macey JR, O’Hara M (2005) pp 571 and 573; Hansmann H (1988) p 294. 
that key employees cannot spread their risks when investing human capital in the firm and are more dependent on the success of that particular start-up. ${ }^{54}$

\subsection{Electronic Voting}

Retail shareholders generally are bad monitors. For this reason, the monitoring of management should be done internally. There should be a two-tier structure at board level and statutory standards based on mandatory provisions of law. Corporate governance generally should be organised in the interests of the firm.

In some cases, powers nevertheless are allocated to shareholders in general meeting and shareholders are entitled to vote. The separation of functions and the need to reduce self-interested decision-making at board level mean that some decisions must be allocated from the board to the general meeting. To reduce costs, shareholders should have a chance to participate via electronic means. A shareholder who casts a vote at a general meeting should have a chance to verify whether the vote has been validly recorded and counted.

The role of proxy voting would need to be different in the proposed small public limited-liability company for two reasons. First, proxy voting rules benefit institutional investors with highly diversified portfolios, many foreign shareholdings, and proxy advisers. ${ }^{55}$ The proposed small public limited-liability company with its microexchange would not be ideal for investment funds to invest in. Second, the company form is proposed for the purpose of increasing retail investors' direct equity investment rather than the holding of shares through chains of intermediaries. ${ }^{56}$

Proxy voting could be replaced by direct electronic voting and mandatory provisions of law addressing the most important issues of concern. ${ }^{57}$

54 For employee share ownership, see already Tarbell IM (1916) pp 230 - 257. For employee ownership when AI robots do more of the work, see Freeman RB (2018). See Macey JR, O'Hara M (2005) p 573 on how sometimes "the capacity of workers to monitor the management of the firm is superior to that of outside investors”. For start-up lawyering, see Coyle JF, Green JM (2017).

55 Recital 25 of Directive (EU) 2017/828 (SRD II). For the regulation of proxy voting advice in the US, see Placenti FM (2019); The Economist, Out with the proxies, 16 November 2019. For the EU, see Schweiger R (2017).

56 See recital 4 of Directive (EU) 2017/828 (SRD II) on how shares of listed companies often are held through complex chains of intermediaries.

57 The Economist, Voting with your pocket, 14 April 2018: “An analysis by Institutional Shareholder Services (ISS), a proxy-advisory firm-which advises fund managers on how to vote on proposals-found that of the 459 shareholder proposals submitted by early April this year, 


\subsection{Facilitating the Use of a Microexchange}

The small public limited-liability company is proposed here as a new company form to facilitate the use of a microexchange, that is, a marketplace for secondary trading in the shares of one company only. Microexchanges are proposed as a means to increase the number of companies with publicly-traded shares and retail investors' direct shareholding in growth firms (section 6.4.13 and Chapter 8).

The new company law regime should therefore make it possible to organise a microexchange, take corporate action relating to the use of a microexchange, signal the quality of an issuer that uses a microexchange, reduce transaction costs for companies using a microexchange, and reduce transaction costs for retail investors trading on a microexchange.

The regulation of microexchanges should be based on mandatory provisions of law. Mandatory provisions can protect investors, ensure the necessary standardisation, prevent a market for lemons, contribute to economies of scale, contribute to technological advancement, and make it easier for investors to compare investments.

There are examples of similar approaches in the past. The company law regime applicable to the German Aktiengesellschaft (AG) has a wide scope and is largely mandatory in order to create public markets and make it easier for investors to compare different investments. ${ }^{58}$ The US Securities Acts of 1933 and 1934 are federal law and mandatory for issuers. Their general purpose was to protect investors and make the business of dishonest issuers more difficult. Moreover, the Securities Acts promote efficiency, competition, and capital formation (section 4.2.3).

To reduce traders' perceived risk exposure, the microexchange should be ring-fenced from the assets of the issuer. This can be achieved by the use of an SPV that is a subsidiary of the small public limited-liability company. The SPV should be incorporated in the same country as its parent company to simplify the regulatory framework, reduce the costs of regulatory compliance, improve monitoring and enforcement, reduce traders' risk exposure, and reduce tax evasion. ${ }^{59}$ In the EU, such an SPV could benefit from the adoption of simpli-

many fell under just a few headings: transparency about political spending, climate change, racial and gender diversity, and pay."

58 See, for example, §23(5) AktG setting out the principle of statute stringency ("Satzungsstrenge”).

59 In the EU, this would raise the question of freedom of establishment under Article 49 of the Treaty on the Functioning of the European Union. According to this proposal, the freedom of establishment should be guaranteed by the freedom to incorporate the proposed small public lim- 
fied procedures for single-member limited liability companies under the proposed SUP (Societas Unius Personae) Regulation. ${ }^{60}$

The traders' risk exposure could further be reduced by obligations owed by the parent company to the SPV. It is in the interests of the parent company to ensure that the operations of the SPV are on a sound basis. ${ }^{61}$ To be in a position to do so, the parent company should have a statutory minimum subscribed capital (section 9.7). Moreover, the parent company could have a company law duty to use its best efforts to ensure that the subsidiary (the microexchange) is in a position to fulfil its obligations or provide for a statutory guarantee for the subsidiary's obligations. Moreover, company law could permit the lifting of the limited liability of the parent company under some circumstances.

There should be rules laying down the decision-making process. Decisions on the use of a microexchange are akin to decisions on listing and delisting.

\subsection{Minimum Share Capital}

There should be a minimum subscribed and paid-for share capital for the proposed small public limited-liability company in the event that it wants to use the proposed microexchange.

On one hand, there should be no high minimum share capital for small public limited-liability companies in general. A high minimum share capital would hamper the use of this proposed new company form. In the EU, the SPE proposal set the minimum capital requirement at $€ 1$ in order to foster the business of startups.

On the other, the use of a microexchange should be reserved for companies that already have survived the seed phase and need more funding for the early expansion phase. There should be a way to signal a difference between such companies and the early-stage high-risk ventures that seek seed funding or crowdfunding. An adequate minimum and paid-for share capital for companies

ited-liability company in the chosen country. A rule that sets out that the parent and the subsidiary in this case must be incorporated in the same country is akin to the rule that the registered office of an SE must be in the country of incorporation. Article 3(1) of Regulation 2157/2001 (SE Regulation).

60 See Conac PH (2015); critically Ghetti R (2018) pp 828-831.

61 Cicero said that a man's home is his castle: "Quid enim sanctius, quid omni religione munitius, quam domus unusquisque civium?” Cited in Book 4, Chapter 16 of William Blackstone's Commentaries on the Laws of England. 
that choose to have their shares traded on a microexchange could be a way to signal a difference between such companies and higher-risk ventures.

Moreover, a minimum share capital requirement would perhaps reduce the risk of abuse, increase the firm's survival chances, reduce retail investors' perceived risk exposure, increase investors' trust in companies that use microexchanges, increase the use of microexchanges, and hopefully increase the number of companies with publicly-traded shares and retail investors' direct equity investments in growth firms.

In EU company law, the required minimum capital depends on the company. The Directive relating to certain aspects of company law provides that the minimum subscribed capital for public limited-liability companies shall be not less than $€ 25,000$. $^{62}$ The SE Regulation lays down a subscribed capital requirement of not less than $€ 120,000 .^{63}$ Both are lower than the Listing Directive's ${ }^{64}$ market capitalisation requirement of at least $€ 1$ million for companies that seek official listing. ${ }^{65}$ A market capitalisation requirement would not work for the small companies that the microexchange is aimed for.

\subsection{One or Two Classes of Shares}

Growth firms often use multiple classes of shares. Should the use of multiple classes of shares be permitted or would a "one share, one vote structure" work better for the firm?

On one hand, one could argue there should be just one class of shares in the proposed small public limited-liability company for reasons of liquidity, transparency, and simplicity.

Shares in start-ups and SMEs are inherently illiquid. Their shares are less illiquid if there is just one class of shares as there will be more shares per class in that case. The use of just one class of shares could help to increase transparency, reduce abuse, and simplify regulation. Traditionally, early investors such as founders and angel investors have tended to subscribe for common equity

62 See Article 45(1) of Directive (EU) 2017/1132 (Directive relating to certain aspects of company law).

63 Article 4(2) of Regulation 2157/2001 (SE Regulation).

64 Directive 2001/34/EC of the European Parliament and of the Council of 28 May 2001 on the admission of securities to official stock exchange listing and on information to be published on those securities.

65 Article 43(1) of Directive 2001/34/EC (Listing Directive). 
shares. The use of just one class of shares would not prevent the use of SAFEs, convertible notes, or other convertible securities (section 7.4).

A rule permitting just one class of shares would prevent the firm from issuing multiple classes of shares only temporarily and would not prevent it from issuing new classes of shares in the future. The firm could issue new classes of shares after changing its company form. After building a sufficient shareholder base and reaching a higher market capitalisation, the company might even be able to fulfil admission requirements and apply for a listing on an SME market.

On the other, the use of multiple classes of shares is common practice in growth firms (section 5.3), that is, the type of firms that the proposed company form is intended for. Moreover, a "one share, one vote structure" is not a legal requirement in US securities law $^{66}$ and EU company law. ${ }^{67}$

To make the proposed microexchange and the proposed small public limited-liability company relevant for founders and growth firms, the better alternative therefore is to permit the use of different classes of shares subject to restrictions balancing the different objectives.

The company should be permitted to use two classes of shares. Shares traded on a microexchange should be common equity each share conferring one vote. When the company uses a microexchange, the company should only be able to issue common equity shares. To make the microexchange and the small public limited-liability company relevant for founders and growth firms, the company should be permitted to have one additional class of shares issued before the commencement of trading on the microexchange.

\subsection{Pre-Emptive Rights, New Funding Rounds and Equal Treatment}

Shareholders' pre-emptive rights and the principle of equal treatment of shareholders should apply in the proposed small public limited-liability company.

66 SEC Release No. 34-85828 (May 10, 2019), III.E.3: "Commission rules do not mandate that the rules of a national securities exchange must provide for a 'one share, one vote' requirement for listed issuers.”

67 Proposal for a Council Regulation on the statute for a European private company, COM(2008) 396 final, Explanatory memorandum, Chapter III: “The Regulation allows shareholders a large degree of freedom to determine matters relating to shares, in particular the rights and obligations attached to shares. An SPE may issue ordinary or priority shares. Restrictions only apply when necessary in the interest of third parties or minority shareholders.” 
Generally, the equal treatment of all shareholders who are in the same position belongs to the most fundamental principles of EU company law. ${ }^{68}$

As regards pre-emptive rights, there is a fundamental difference between EU company law and US company law. Pre-emptive rights have their roots in continental European company law and are part of EU company law. ${ }^{69}$ The right to decide on the issuing of shares and the waiving of pre-emptive rights is vested in the general meeting under the Directive relating to certain aspects of company law. ${ }^{70}$ The Directive seems to provide a balance between shareholder protection and flexibility. In the US, all powers in the company customarily are vested in the board under the company's by-laws (section 2.4.10). Pre-emptive rights do not apply. In venture capital practice, however, it is customary to agree on the protection of shareholders in later funding rounds and in exits (section 5.3).

In the proposed small public limited-liability company, it should be made relatively easy to waive pre-emptive on a case-by-case basis to enable private placements, and there should be an exemption for the issuing of shares on an on-going basis under a programme.

A growth firm needs private placements. Private placements tend to be oneoff transactions. When the company issues new shares to investors after waiving the pre-emptive rights of existing shareholders ad hoc, the price payable for the shares should not be lower than the fair value of the new shares based on the valuation of similar companies.

A growth firm could even benefit from a chance to sell existing shares or issue new shares to investors on an on-going basis under a programme. This is the opposite of a share buy-back programme. An exemption from pre-emptive rights for such a programme could be motivated if the programme is limited and the decision to adopt it requires shareholder consent.

\subsection{Exits and the Market for Corporate Control}

Both the free transferability of shares and the market for corporate control would need to work in a different way in the proposed small public limited-liability company. There should be lock-ins for the most important shareholders and tag-along rights (co-sale rights) for other shareholders.

68 Article 85 of Directive (EU) 2017/1132 (Directive relating to certain aspects of company law). 69 Article 72(1) of Directive (EU) 2017/1132 (Directive relating to certain aspects of company law). 70 Articles 68(1) and 72(4) of Directive (EU) 2017/1132 (Directive relating to certain aspects of company law). 
Lock-ins and tag-along rights. The survival of a start-up largely depends on the quality of its founders and controlling shareholders. To increase the survival chances of the firm, the firm should have good controlling shareholders that contribute to the firm's long-term success. When the firm chooses to raise funding, potential investors will look at the quality of the founders and controlling shareholders. Diligent investors will do the same in secondary trading.

In corporate practice, it is customary to restrict the sale and purchase of shares. ${ }^{71}$ In SME exchange practice, lock-ins for major shareholders have been used as a means to reduce illiquidity for other shareholders (section 6.3.14), and to align interests. In venture capital practice, founders may undertake non-compete obligations, obligations to work for the company in different capacities, and restrictions on share sales (section 5.3). Restrictions on exits are complemented by tag-along rights (or co-sale rights) in the event of exit. Tagalong rights are common practice in venture capital transactions. In US regulatory practice, the JOBS Act and Regulation Crowdfunding restrict resales (section 7.3).

Since new investors rely on the quality of the most important shareholders when assessing the quality of the firm, the interests of the core shareholders should be aligned with the long-term interests of the firm at least for a limited period of time.

For these reasons, market practice should be reflected in the use of statutory time-limited lock-ins for the most important shareholders after the issuing of new shares or the commencement of secondary trading on the microexchange. Moreover, where a controlling block of shares is sold during a pre-defined time period, other shareholders should have tag-along rights (or co-sale rights). Agreed tag-along rights tend to have a wider scope than the sell-out rights and the mandatory bid rule under the EU's Takeover Bid Directive. ${ }^{72}$ A functional equivalent of a tag-along right can be created by a mandatory bid rule (see below).

One may ask whether the controlling shareholder should have a squeeze-out right, or no squeeze-out right unless the company form is changed first. ${ }^{73}$ Again,

71 See, for example, Hornstein GD (1950) pp 1047-1051 on closely held corporations; Mäntysaari P (2010c) Chapter 18 on takeover defences.

72 See Article 16 of Directive 2004/25/EC (Directive on takeover bids) on the sell-out right; Article 5(1) on the mandatory bid.

73 Compare the proposal for a Council Regulation on the statute for a European private company, COM(2008) 396 final, Explanatory memorandum, Chapter III: "The Regulation does not provide shareholders with the right to squeeze-out minority shareholders. Nor does it put an obligation on the majority shareholder or the SPE to buy the shares of the minority shareholder 
it is a question of balancing different interests. Small shareholders either may or may not want to part with their shares. The firm may benefit from a more dispersed share ownership structure or from having a sole shareholder. A controlling shareholder may need more discretion. Small shareholders may or may not benefit from the work of the controlling shareholder. In the light of the variety of these situations, the better alternative seems to be to increase flexibility for firms and controlling shareholders and choose a squeeze-out right for the proposed small public limited-liability company. There will be neither publicly-traded shares nor retail investors in the first place unless it is in the interests of firms and controlling shareholders.

Market for corporate control. Traditional stock exchanges and listed companies need rules for the market for corporate control. ${ }^{74}$ If a traditional listed company is in the market for corporate control, the cost of shareholders as the firm's agents is increased, because the firm will need to invest more in structural takeover defences.

However, a start-up or a small growth firm customarily is not in the market for corporate control. It does not need to invest in structural takeover defences, because it has a concentrated share ownership structure. Where controlling shareholders sell their block of shares, corporate control changes hands.

One may therefore ask how to address the question of mandatory bids and public takeover bids in the context of the proposed small public limited-liability company.

A mandatory bid rule does not seem problematic. On one hand, the existence of a mandatory bid rule might hamper control transactions. On the other, a mandatory bid rule can also be regarded as a functional equivalent of tag-along rights that are common practice in venture capital transactions. Either a mandatory bid rule or mandatory tag-along rights could therefore be regarded as suitable for the proposed small public limited-liability company.

As regards public takeover bids, the most important rule for the firm is the absence of a board duty to accept the bid. In the EU, the Takeover Bid Directive

(sell-out right). Such provisions may be adopted in the articles of association. However, the Regulation allows both the expulsion and the withdrawal of a shareholder under specific circumstances."

74 See, for example, Christiansen H, Koldertsova A (2009) p 211: "This consideration is reflected in section II.E of the OECD Principles of Corporate Governance which stresses the importance for corporate governance of markets for corporate control functioning in an efficient and transparent manner." 
does not lay down any such duty. The target's board may thus say no. ${ }^{75}$ In Delaware, the target's board has a right to defend the "corporate bastion" in the light of Unocal and Revlon. ${ }^{76}$

\subsection{Use of Capital}

Each firm has its own capital needs. Generally, the company's capital should be used in the interests of the firm (section 6.3.2). There should be restrictions on the distribution of assets to shareholders. The proposed small public limited-liability company has its particular characteristics that should be reflected in the regulation of the use of capital.

The proposed small public limited-liability company is a company form for growth firms. A young growth firm should focus on growth in order to survive. The distribution of assets to shareholders would be likely to hamper growth and make the firm's prospects worse. For this reason, it would be necessary to limit the amounts that may distributed to shareholders, and to regulate the decision-making process.

In other words, the legal capital regime should be stricter than in existing public limited-liability companies to make it more difficult for controlling shareholders to use their powers to distribute funds to themselves. ${ }^{77}$

Moreover, shareholders should not have a legal right to force the board to distribute assets to shareholders. Minority shareholders should have a right to veto the board's proposals on the distribution of assets to shareholders. ${ }^{78}$

75 See Articles 3(1)(b), 3(1)(c) and 9 of Directive 2004/25/EC of the European Parliament and of the Council of 21 April 2004 on takeover bids.

76 Revlon, Inc. v. MacAndrews \& Forbes Holdings, Inc. 506 A.2d 173 (Del. 1986); Unocal Corp. v. Mesa Petroleum Co., 493 A.2d 946 (Del. 1985).

77 For the legal capital regime, see Mäntysaari P (2010c) sections 5.3 and 5.4; Chapter IV of Directive (EU) 2017/1132 (Directive relating to certain aspects of company law).

78 The SPE proposal would have provided for more flexibility. Proposal for a Council Regulation on the statute for a European private company, $\operatorname{COM(2008)} 396$ final, Explanatory memorandum, Chapter IV. 


\subsection{Monitoring and Enforcement}

Generally, the regulation of the monitoring and enforcement functions of the proposed small public limited-liability company should be based on mandatory provisions of law. Where the company is a traditional company listed on a traditional exchange, these functions and many other corporate governance issues (section 2.3.3) can to some extent be regulated and enforced by the exchange. ${ }^{79}$ The regulatory trend nevertheless is the increasing role of mandatory provisions of law.

The proposed small public limited-liability company that uses a microexchange is not like a traditional listed company, since the proposed microexchange is just an extended arm of the issuer and cannot have any rule-making function. A high level of standardisation would be necessary to increase transparency, reduce costs, and prevent a market for lemons.

Statutory rules on the monitoring and enforcement function of the proposed small public limited-liability company would have many potentially conflicting objectives. On one hand, it would be necessary to protect retail investors and other small shareholders to reduce their perceived risk exposure, increase the valuation of the company's shares, and reduce the cost of funding. On the other, all long-term shareholders will lose unless the business venture is successful. For this to happen, the people that run the company should have enough discretion to act in the interests of the firm and a legal duty to do so (sections 3.4.13 and 6.3.2). Moreover, shareholder objectives depend on the characteristics of the shareholder. Minority shareholders and controlling shareholders do not necessarily share the same objectives ${ }^{80}$ They do not provide identical services to the firm. It would be beneficial to empower shareholders to the extent that they provide good services.

Rules on monitoring and enforcement should, therefore, balance conflicting objectives. We propose the following design principles that largely relate to structural measures.

First, from the perspective of the issuer, the self-enforcement of the governance model ${ }^{81}$ is more important than monitoring by all shareholders. Before the German company law reform of 1884 , it was understood that small share-

79 For the rule-making duties of LTSE, see SEC Release No. 34-85828 (May 10, 2019), III.E.3. For the "regulatory functions" of traditional exchanges, see even Christiansen $\mathrm{H}$, Koldertsova A (2009) p 212.

80 Hornstein GD (1950); Mäntysaari P (2010a) section 8.7.6 and Chapter 9.

81 Mäntysaari P (2012) Chapter 8. 
holders do not make good monitors (section 2.4.5). Shareholders can nevertheless provide monitoring services that complement or contribute to the self-enforcement of the governance model. From the perspective of the firm, facilitating such monitoring services is a means to an end rather than an end itself. ${ }^{82}$

Second, it is possible to improve monitoring by using a two-tier board with the supervisory board monitoring the management board and voting on proposals submitted by the management board in important matters. A self-enforcing governance model with a clear separation of the monitoring function from the management function would make it less necessary for small shareholders to participate in monitoring. The two-tier model should be complemented by general statutory duties for members of the two boards. Under a two-tier board model, transparent company law duties even apply to top managers, whereas in a one-tier board model, the duties of top managers often fall outside the scope of company law and are based on less transparent contracts. Under a two-tier board model, board committees are not necessary for monitoring purposes, and the independence of individual board members is less relevant. ${ }^{83}$ The management board can be replaced by a managing director or directors (Geschäftsführer).

Third, to protect shareholders, a legal capital regime could be used to give shareholders a right to vote on the board's proposals in important transactions that influence their shares or the company's legal capital. ${ }^{84}$ The required majority can either be low and increase management discretion (and the discretion of controlling shareholders), or high and make it easier to block decisions (and reduce the power of controlling shareholders). A rule requiring a simple majority

82 See even Macey JR, Kanda H (1990) p 1021: "To the extent that the enhanced monitoring available on organized exchanges lowers monitoring costs, firms will be willing to pay to have their shares listed on such exchanges."

83 Mäntysaari P (2005) pp 404 and 422. For corporate governance on traditional securities markets, see, for example, SEC Release No. $34-85828$ (May 10, 2019), III.E.3: "LTSE has proposed corporate governance standards in connection with securities to be listed and traded on LTSE that are substantially similar to the corporate governance listing standards of other exchanges. Included in these standards are rules requiring a majority of directors on a listed issuer's board to be independent; rules and independence requirements relating to audit and compensation committees and the oversight of nominations; and rules requiring listed issuers to adopt codes of conduct applicable to all their directors, officers and employees.”

84 For the legal capital regime, see Mäntysaari P (2010c) sections 5.3 and 5.4; Bebchuk LA (2005). 
of votes cast could increase management discretion and the discretion of controlling shareholders as controlling shareholders vote for the board's proposal. ${ }^{85}$

Fourth, the use of just one or two classes of shares would increase transparency and help to improve the quality of monitoring and enforcement. This would not prevent the firm from using multiple classes of shares in the long term, because the firm would be able to use multiple classes of shares when it changes its company form. For example, the firm could change its company form to raise venture capital funding or enter regular stock markets.

Fifth, litigation should be restricted. Inherently high-risk business projects will not happen unless legal liability is limited. This has already contributed to the emergence of separate legal entities, the limited liability of shareholders, the business judgment rule, limitations on shareholders' direct action against people whose duties are owed to the company, and limitations on shareholders' derivative actions. In practice, board members in large companies have rarely been made liable for loss or damage caused to the company. If the same tests - and the business judgment rule - were applied in the high-risk environment of start-ups, growth firms, technology firms, and digital economy, the actual exposure of board members to legal liability would perhaps remain sufficiently low. Shareholder action can nevertheless hamper the business of the firm and increase costs even where the action is groundless or bound to fail. It would, therefore, be necessary to reduce minority shareholders' opportunities to bring legal proceedings against board members or the company. ${ }^{86}$

Sixth, small public limited-liability companies should be monitored by financial supervision authorities. For example, the SEC explained the duties of an exchange in a 2019 release "In the Matter of the Application of Long Term

85 Compare the proposal for a Council Regulation on the statute for a European private company, $\operatorname{COM(2008)} 396$ final, Chapter V: "The shareholders of the SPE enjoy a high degree of freedom in determining the internal organisation of the SPE, subject to the Regulation. Article 27 provides a non exhaustive list of the decisions which must be taken by shareholders. The articles of association must set out the required majority and quorum for voting subject to Article 27 which provides that certain of these decisions require a qualified majority (i.e., at least $2 / 3$ of the voting rights of the SPE, but the articles may provide for a greater majority, e.g. 3/4) ... All decisions which are not listed in the Regulation or in the articles of association fall under the competence of the SPE's management body which is responsible for running the company." 86 See also the proposal for a Council Regulation on the statute for a European private company, $\operatorname{COM}(2008) 396$ final, Chapter V: "The Regulation imposes on directors the duty of acting in the best interests of the company. Accordingly, directors' duties are owed to the SPE and may only be enforced by the company. The Regulation does not give individual shareholders or creditors the right to directly sue the members of the management body.” 
Stock Exchange, Inc. for Registration as a National Securities Exchange". ${ }^{87}$ Such duties should belong to public authorities in the absence of an exchange that could have a monitoring role. Moreover, criminalisations can help to reduce the risk of fraud and abuses.

\subsection{Change of Company Form and Conclusions}

The proposed small public limited-liability company is designed as a tailor-made company form for small firms that choose to have publicly-traded shares. The proposed company form goes hand in hand with the use of a microexchange.

The proposed company form would not necessarily be the first company form of the firm. It could be followed by a traditional company form when the firm chooses a listing on a traditional exchange, is taken over, or goes private. The firm's preferences may change over time. ${ }^{88}$ For these reasons, it should be made easy for firms to opt in the regulatory regime for small public limited-liability companies, and to opt out by choosing another company form.

It seems possible to develop design principles that are aligned with the particular interests of such firms. The "smorgasbord" of these design principles could to some extent even be used as a model for a general company law reform.

\section{References}

Adams RB, Ferreira D (2007) A theory of friendly boards. Journal of Finance 62(1):217-250 Antunes JE, Baums T, Clarke BJ, Conac PH, Enriques L, Hanak Al, Hansen JL, de Kluiver HJ, Knapp V, Lenoir N, Linnainmaa L, Soltysinski S, Wymeersch EO (2011) Report of the Reflection Group on the Future of EU Company Law. European Commission, Internal Market and Services, 5 April 2011

Belot F, Ginglinger E, Slovin MB, Sushka ME (2014) Freedom of Choice between Unitary and Two-Tier Boards: An Empirical Analysis. Journal of Financial Economics 112(3):364-385

Callison W, Fenwick M, McCahery JA, Vermeulen EPM (2018) Corporate Disruption: The Law and Design of Organizations in the Twenty-First Century. European Business Organization Law Review 19:737-769

Christiansen H, Koldertsova A (2009) The role of stock exchanges in corporate governance. OECD Journal: Financial Market Trends, vol. 2009/1 pp 209-238. OECD, Paris

Conac PH (2015) The Societas Unius Personae (SUP): A "Passport" for Job Creation and Growth. European Company and Financial Law Review 12(2):139-176

87 SEC Release No. 34-85828 (May 10, 2019), III.D.

88 See, for example, Macey JR, O’Hara M (2005) p 576 distinguishing between firms' preferences for regulation before and after the issuing of shares to the public. 
Conard AF (1975) The Corporate Census: A Preliminary Exploration. California Law Review 63(2):440-462

Coyle JF, Green JM (2014) Contractual Innovation in Venture Capital. Hastings Law Journal 66:133-183

Eisenberg MA (1969) The Legal Roles of Shareholders and Management in Modern Corporate Decisionmaking. California Law Review 57(1):1-181

Ghetti R (2018) Unification, Harmonisation and Competition in European Company Forms. European Business Law Review 29(5):813-842

Giudici P, Agstner P (2019) Startups and Company Law: The Competitive Pressure of Delaware on Italy (and Europe?) European Business Organization Law Review 20:597-632

Giudici P, McCahery JA (2019) Close Corporations and the Financing of SMEs: An Introduction. European Business Organization Law Review 20:591-595

Gilson RJ (2014) Chapter IV. The Nordic Model in an International Perspective: The Role of Ownership. A comment. In: Lekvall P (ed) The Nordic Corporate Governance Model. SNS Förlag, Stockholm, pp 94-113

Hansmann H (1988) Ownership of the Firm. Journal of Law, Economics, and Organization 4(2):267-304

Hopt KJ (2018) Corporate Governance und Krise: Verwaltungsrat und/oder Vorstand und Aufsichtsrat in Europa. In: Binder JH, Psaroudakis G (eds) Europäisches Privat- und Wirtschaftsrecht in der Krise. Mohr Siebeck, Tübingen, pp 269-282

Hornstein GD (1950) Stockholders' Agreements in the Closely Held Corporation. Yale Law Journal 59(6):1040-1056

Ibrahim DM (2008) The (Not So) Puzzling Behavior of Angel Investors. Vanderbilt Law Review 61(5):1405-1452

Kitch EW (2005) The Simplification of the Criteria for Good Corporate Law or Why Corporate Law Is Not as Important Anymore. Berkeley Business Law Journal 2(1):35-38

Koutsias M (2019) Exit Britain Enter the Stakeholders: Could Brexit end the cultural wars within the European Union Company Law and give birth to a truly "European Company"? European Business Law Review 30(6):881-908

Macey JR, Kanda H (1990) Stock Exchange as a Firm: The Emergence of Close Substitutes for the New York and Tokyo Stock Exchanges. Cornell Law Review 75(5):1006-1052

Placenti FM (2019) The SEC's Evolving Views Regarding Proxy Advisors. Harvard Law School Forum on Corporate Governance, November 23, 2019

Schweiger R (2017) § 28 Proxy Advisors. In: Veil R (ed) European Capital Markets Law. Second Edition. Hart Publishing, Oxford and Portland, pp 575-595

Willekens M, Dekeyser S, Simac S (2019) EU Statutory Audit Reform: Impact on costs, concentration and competition. Document requested by the European Parliament's Committee on Economic and Monetary Affairs (ECON). European Union 